\title{
FONOLOŠKO-GRAMATIČKI INTERFEJS SLOGOVNOG AKCENTA
}

\begin{abstract}
U radu se slogovni akcenat posmatra kao reprezentativni fenomen interfejsa fonologije odnosno prozodije i drugih jezičkih modula, na primeru akcenatskog sistema albanskoga jezika. Iznosi se sinteza dosadašnje teorijske literature o slogovnom akcentu uopšte, kao i literature o slogovnom akcentu u albanskom jeziku. Teorijski pristupi slogovnom akcentu razmatraju se u odnosu na njihovu deskriptivnu i eksplanatornu adekvatnost, kao i u vezi sa pitanjima koja pokreću i u širem teorijskom, morfološkom i sintaktičkom kontekstu.
\end{abstract}

Ključne reči: opšta fonologija, slogovni akcenat, fonološko-gramatički interfejs, albanski jezik.

\section{Uvod}

Predmet ovoga rada jeste akcenatski sistem kao fenomen interfejsa fonologije odnosno prozodije i morfosintaktičke komponente jezika. U radu se analizira prozodijska organizacija i akcenatska struktura (izgovorne) reči, na materijalu albanskog jezika. Cilj istraživanja jeste teorijsko i tipološko određenje slogovnog (leksičkog) akcenta kao kompleksnog fonetsko-fonološkog i gramatičkog sredstva demarkacije reči.

Rad je organizovan u tri celine. U prvome delu rada daje se pregled ključnih pojmova iz opšte fonetike i fonologije govornih suprasegmenata, kao i tipološka i deskriptivna analiza slogovnog akcenta u albanskom jezi$\mathrm{ku}$, čime se postavljaju osnove i građa za dalje izlaganje.

Drugi deo rada sadrži prikaz dosadašnje teorijske literature o akcentu u albanskom jeziku. Postojećim istraživanjima obuhvaćena je većina glavnih pristupa slogovnom akcentu u okviru generativne fonologije:

\footnotetext{
Studentski trg 3, Beograd, djordje.bozovic@fil.bg.ac.rs.
} 
standardni generativni model, leksikalistički pristup i ciklička fonologija, metrička teorija i teorija optimalnosti.

U trećem poglavlju detaljnije se analizira slogovni akcenat $u$ albanskom jeziku kao fenomen fonološko-gramatičkog interfejsa i daje se sinteza i zaključci uočenih pojava. Iznosi se morfonološka analiza infektuma u albanskom jeziku, sa alternacijama $n: j$ i $n: \varnothing$, u svetlu mesta slogovnog akcenta u glagolskoj osnovi; kao i prikaz nekih aspekata kliticizacije i linearizacije klitičkoga niza.

\subsection{Osnove prozodije: fonetika i fonologija suprasegmenata}

Prozodija (prema grč. $\pi \rho 0 \sigma \omega \delta i ́ \alpha)$ u lingvističkom smislu podrazumeva varijacije u produkciji artikulaciono-akustičkih, odnosno percepciji auditivno-akustičkih obeležja govora, poput frekvencije odnosno visine, trajanja odnosno tempa govora i intenziteta odnosno glasnoće. Varijabilna obeležja govornih segmenata - glasa, sloga, izgovorne reči ili fonetske fraze - koja imaju lingvističku i komunikativnu funkciju nazivaju se suprasegmentima, budući da se u najvećem delu fonološki realizuju na višim nivoima hijerarhijske organizacije govornog niza (Clark \& Yallop 1990: 276-295; Cruttenden 1997; Fox 2000; Kašić 2000a; Ladd 1996; Lehiste 1970).

Varijabilnost je, međutim, neizbežna i stalna pojavna karakteristika širokog spektra fonetskih obeležja govornih segmenata, uključujući i inherentna fonetska obeležja. Uz to što se većina fonetskih obeležja govornih segmenata mogu i hotimično varirati, na varijaciju u produkciji artikulacionoakustičkih obeležja govornog signala u najvećoj meri utiču i brojni nehotimični spoljašnji faktori, poput kvaliteta kanala komunikacije, opšteg zdravstvenog i psihičkog stanja govornika ili šireg društvenog konteksta u kom se odvija komunikacijski čin. Spektar varijabilnih govornih obeležja, tako, uključuje i drugačije međusobno sasvim nepovezana obeležja, poput zvučnosti, nazalizovanosti, trajanja, intenziteta ili frekvencije i dr. Pojedine njihove varijacije nose pragmatičke i sociolingvističke funkcije u određenim kontekstima, većina su pak ekstralingvističke ili paralingvističke prirode, dok su tek pojedine od njih u većoj meri fonologizovane $\mathrm{u}$ artikulacionim bazama izvornih govornika različitih idioma (Kašić 2000b).

Među govornim suprasegmentima s najstalnijim karakteristikama u artikulacionim bazama konkretnih idioma jeste slogovni ili leksički akcenat (naglasak, akcenat reči). Akcenat predstavlja relativno isticanje jed- 
nog govornog segmenta u odnosu na druge na istom nivou hijerarhijske organizacije govornog niza, variranjem određenog ili više združenih prozodijskih obeležja - intenziteta, frekvencije i trajanja (cf. i Hulst 2014). Slogovni akcenat, tako, predstavlja relativno isticanje određenog sloga $\mathrm{u}$ (izgovornoj) reči, u odnosu na druge slogove, variranjem njihovog intenziteta, frekvencije ili trajanja. Osim te vrste akcenta, lingvističku i komunikativnu funkciju može imati i relativno isticanje jedne reči u sintagmi sintagmatski akcenat; te relativno isticanje jedne reči ili sintagme u iskazu - rečenični akcenat ili intonacija; tj. jednom rečju, prozodijska struktura iskaza (Belić 1931; Peco 1991: 87-103; Zec 1997; za albanski cf. Boriçi 1987; Dodi 1986).

Slogovni akcenat, kao jedno od najstalnijih i najfonologizovanijih suprasegmentnih obeležja, predstavlja i jezičku univerzaliju prve vrste nema jezika bez fonologizovanoga slogovnog akcenta - „realnog akcenta“ - budući da je njegova primarna lingvistička funkcija demarkacija reči u percepciji kontinuiranog govornog niza (Garde 1993: 13-14; Hyman 2014; Peco, op. cit.: 14-15; kulminativna i delimitativna funkcija akcenta u Trubetzkoy 1968: 29). Otuda je i izražena tendencija u mnogim jezicima da se slogovni akcenat tipično vezuje za granice reči ili za morfemske granice - inicijalni slog, kao u češkom ili u mađarskom; finalni slog, kao u francuskom; penultimu, kao u poljskom; najdalje antepenultimu, kao u makedonskom; odnosno tri finalne more, kao u grčkom; dve finalne more, ne računajući ekstrametričnu ultimu, kao u latinskome, i sl.; dok u pojedinim jezicima, poput ruskoga ili engleskoga, morfološka struktura reči u celini određuje i mesto slogovnog akcenta (Garde, op. cit.: 76-104). U tome smislu može se razumeti i novoštokavska retrakcija akcenta - metatonija, kao tendencija ka približavanju i fiksiranju mesta akcenta bliže početku (sintaktičke) reči.

S tim u vezi, tipološku klasifikaciju slogovnih akcenata prema njihovom položaju unutar reči u fonološkim sistemima različitih jezika, na vezane i slobodne (Garde, op. cit.: 10-12, ibid.; Peco, op. cit.: 19-22; Trubetzkoy 1958; op. cit.), treba shvatiti dosta uslovno. Radi se, pre svega, o formalnoj opservaciji u vezi s morfonološkim opsegom akcenatskih alternacija u artikulacionim bazama konkretnih idioma. Slogovni akcenat je vezan ukoliko je njegovo mesto određeno fonološkom strukturom reči (metričkom organizacijom slogova odnosno mora), dok je slobodan utoliko što je njegovo mesto određeno morfonološki, tj. prozodijskom or- 
ganizacijom morfema u sastavu reči (Garde, op. cit.: 21). U oba slučaja, međutim, reč je o istome fenomenu - prozodijskoj organizaciji morfološke strukture; i u tome smislu nema niti formalne razlike između slobodnih i vezanih akcenata. Bilo da je slogovni akcenat vezan ili pokretan (mobilan) u paradigmi različitih reči, on je kao morfonološki fenomen par excellence u svakom slučaju osetljiv na njihov morfološki sastav; i ni u kom slučaju nije potpuno slobodan, kao što nikada nije niti vezano, morfo(no) loški redundantno obeležje samih govornih segmenata. To će se, niže u radu, pokazati i analizom slogovnog akcenta u albanskom jeziku, koji je ujedno fonološki vezan metričkom strukturom, nepomičan u fleksiji, ali i ciklički osetljiv na morfološku informaciju, te pomičan u derivaciji. Funkcionalizmu Trubetzkoga (ibid.) u tom pogledu suprotstavlja se Martinetov (1954; 1982) i Gardeov (ibid.) funkcionalizam i historicizam, kao i generativna fonologija (cf. Chomsky et al. 1956; Mandić 2007).

Pored tipoloških razlika u mestu slogovnog akcenta u reči, tj. u načinu prozodijske organizacije morfonološke strukture reči, kroslingvistički se javljaju i razlike u načinu postizanja relativne istaknutosti akcentovanoga sloga, tj. razlike u upotrebi fonetski i fonološki raspoloživih prozodijskih sredstava za realizaciju slogovnog akcenta. Prema tome kriteriju, moguće je razlučiti dinamičku (ekspiratornu ili kulminativnu), tonsku i visinsku (muzičku, melodijsku ili hromatsku) akcentuaciju (Jakobson 1971; Peco, op. cit.: 16-18; Trubetzkoy, op. cit.), ali i različita srodna ili ,pomoćna“ suprasegmentna obeležja kako akcentovanih, tako i neakcentovanih slogova u reči, pre svega kvantitet i kvalitet akcentovanih i neakcentovanih vokala (Garde, op. cit.: 41-51). Međutim, i tipološku klasifikaciju akcenatskih sistema prema vrsti odnosno načinu ostvarivanja slogovnog akcenta takođe treba shvatiti donekle uslovno. Prema Trubetzkome (1968: 180), akcenat predstavlja pojačavanje audibilnosti jednoga govornog segmenta, sloga odnosno more, u odnosu na druge, bez obzira na to na koji način se ono postiže - bilo promenom intonacije, dakle muzičkom akcentuacijom; ili promenom intenziteta, što će reći dinamičkom akcentuacijom; bilo duljenjem akcentovanog sloga te redukcijom neakcentovanih, ili drugim fonetskim sredstvima. Jakobson (op. cit.), na sličan način, razliku između dinamičke i muzičke akcentuacije objašnjava razlikama u strukturnoj realizaciji akcenatskog kontrasta - $\mathrm{u}$ jezicima s dinamičkom akcentuacijom, kontrast se ostvaruje između slogova; dok se u jezicima s muzičkom akcentuacijom akcenatski kontrast ne podudara nužno sa silabičkom strukturom 
reči, već može da se realizuje i unutar akcentovanoga sloga, tj. u moraičkoj strukturi. U oba slučaja, međutim, nije od značaja konkretno fonetsko sredstvo kojim se akcenatski kontrast postiže. Tim pre što se pojačavanje audibilnosti akcentovanog sloga u različitim jezicima, bez obzira na tip akcentuacije koji u njima dominira, u pravilu i postiže udruženim variranjem više od jednog suprasegmentnog obeležja; dakle glasnoće uz visinu tona i duljenje, ukoliko je reč o dinamičkoj akcentuaciji, odnosno variranjem visine tona uz varijacije i glasnoće, i trajanja akcentovanog i neakcentovanih slogova, ako je reč o tonskoj akcentuaciji.

Dalje, tipološka klasifikacija akcenatskih sistema povlači i pitanje tipa akcenatskih jedinica uopšte i prozodijske strukture u različitim jezicima; prema Jakobsonu (ibid.), sloga ili more, jedinice manje od sloga. Ipak, i jezicima s dinamičkom akcentuacijom poznata je moraička struktura, kako će se i analizom slogovnog akcenta u albanskome pokazati niže u radu. Bez obzira na to poznaju li kvantitetske fonološke opozicije i da li u načinu realizacije slogovnog akcenta dominira intenzitetska ili tonska sastavnica, i mora jeste, kao jedinica slogovne rime, univerzalna prozodijska jedinica - temporalna jedinica, za razliku od sloga, koji je strukturna jedinica. U jezicima bez kvantitetskih opozicija, moraička i silabička struktura reči podudaraju se u odnosu jedan na jedan, ali to ne znači da temporalni, moraički nivo prozodijske strukture u njima izostaje. S time u vezi jeste i izohronijska klasifikacija jezika, koju predlaže Pike (1972), takođe dovedena u pitanje empirijskim istraživanjima (v. Roach 1982); kao i generalizacije o međuodnosu kvantiteta i kvaliteta akcentovanih i neakcentovanih slogova prema tipu akcentuacije odnosno načinu prozodijske organizacije reči u različitim jezicima, poput jampsko-trohejskog zakona (Hayes 1985), a koje su se jednako pokazale diskutabilnim (cf. Crowhurst \& Teodocio Olivares 2014; Revithiadou 2004).

Sve što je napred rečeno o tipološkim klasifikacijama akcenatskih sistema koje su postulirali mladogramatičari i praški strukturalisti, kao i o različitim generalizacijama zasnovanima na njima, upućuje, dakle, upravo na zaključak da idealnotipska rešenja i generalizacije u empiriji ne postoje. Konvencionalnosti radi, u ovom radu se ipak neće mnogo odstupati od standardne strukturalističke terminologije i koncepata (npr. kada se kaže da je slogovni akcenat u albanskome dinamičkog tipa), ali ih uvek treba uzeti i s neophodnom dozom kritičke rezerve (cf. i Hulst 2010). 
Fonetsku i fonološku osnovu slogovnoga akcenta čine, kako je rečeno, varijacije u intenzitetu (jačini) odnosno glasnoći, frekvenciji (visini) odnosno intonaciji, trajanju i drugim prozodijskim ili inherentnim govornim obeležjima svih segmenata izgovorne reči - ne samo akcentovanog sloga; koje Garde (ibid.) naziva pozitivnim i negativnim akcenatskim postupcima. Ni ova klasifikacija, međutim, nije bez mana - u gegijskom dijalektu albanskoga je, recimo, nazalizacija usko povezana s kvantitetom i slogovnim akcentom (Gjinari 1981). Ipak, u najvećem broju slučajeva fonetsku i fonološku bazu akcenatskih sistema u različitim idiomima čine suprasegmentna obeležja intenziteta, tj. glasnoće, tonaliteta i trajanja odnosno dužine - što su i osnovna akustička obeležja govornog signala.

Intenzitet (jačina ili silina), kao artikulaciono-akustičko obeležje, predstavlja opštu snagu, tj. jačinu govornih segmenata prilikom njihovog izgovora, merenu decibelima $(\mathrm{dB})$ u odnosu na prag čujnosti, koju proizvodi mišićna napetost govornih organa tako što stvara pritisak na čestice vazduha. Intenzitet je proporcionalan amplitudi vibracije vazdušnih čestica čije je kretanje uzrokovano opštom snagom zvučnog signala. Jačina je, prema tome, i inherentno govorno obeležje svakog glasa, ali i relativno obeležje u odnosu na druge segmente u govornom nizu. Na suprasegmentnom nivou organizacije govornog izraza, intenzitetu govora delimično odgovara auditivno-akustičko obeležje doživljene glasnoće (glasnosti) govora, izraženo u jedinicama son i fon. Pored fizičke jačine govora, odnosno amplitude, na utisak glasnoće, međutim, u znatnoj meri utiču i druga akustička obeležja, pre svega frekvencija, kao i trajanje govora. Glasnost jeste i ključna sastavnica slogovnog akcenta, jer se pojačavanjem audibilnosti akcentovanog sloga pre svega doprinosi njegovoj relativnoj istaknutosti koja omogućava realizaciju akcenatskog kontrasta u njegovim lingvističkim funkcijama; bilo da se u konkretnim artikulacionim bazama ona primarno postiže variranjem intenziteta ili visine tona.

Frekvencija govora predstavlja broj vibratornih ciklusa glasnica u sekundi prilikom artikulacije govornog signala, meren u hercima $(\mathrm{Hz})$ u SI sistemu jedinica. Budući da je govor složen zvuk, pored osnovnog laringalnog tona $\left(\mathrm{F}_{0}\right)$ koji proizvodi vibriranje glasnih žica pri prolasku vazdušne struje, on sadrži i različita pojačana frekvencijska područja formanata na osnovu kojih se diskriminišu različiti glasovi. Dakle, ukupnost artikulaciono-akustičkih frekvencijskih karakteristika glasova predstavljaju inherentna govorna obeležja, ali su i ona podložna varijaciji, kako 
hotimičnoj, kao i individualnoj varijaciji usled razlika u fonetskom kapacitetu pojedinačnih osoba, tako i pozicionim varijacijama u toku produkcije kontinuiranog govora. Variranje frekvencije osnovnog tona, tako, predstavlja i osnovu auditivno-akustičkog obeležja visine tona, mada i na percepciju visine tona utiču i druga akustička obeležja, pre svega intenzitet. Variranje visine tona u toku govora predstavlja suprasegmentno obeležje intonacije ili melodije govornog izraza, koja ima i različite lingvističke funkcije, od prozodijske organizacije gramatičke strukture iskaza do određenih pragmatičkih ili stilskih funkcija. Jedna od lingvističkih funkcija intonacije jeste i njena uloga u realizaciji akcenatskog kontrasta, bilo da je pri tome tonalitet primarno ili redundantno akcenatsko sredstvo.

Govorni signal odlikuje se i objektivnim i subjektivnim trajanjem, vremenom koje je potrebno za artikulaciju i percepciju određenog govornog segmenta. Nas ne zanima objektivno trajanje kao artikulaciono-akustičko obeležje kao takvo u kontekstu ovoga rada, niti subjektivno trajanje kao auditivno-akustičko obeležje, već pre svega njegova uloga u prozodijskoj organizaciji govornog izraza. Varijacije trajanja u kontinuiranom govornom toku osnov su različitih suprasegmentnih obeležja, poput tempa govora, a i u mnogima drugima imaju važnu pomoćnu ulogu, poput akcenta. Osim toga, ovde nas zanima i relativno trajanje govornih segmenata koje je u artikulacionim bazama nekih jezika fonologizovano kao prozodijsko obeležje dužine (kvantiteta), koje se iskazuje u temporalnim jedinicama morama (prema lat. mora). Dužina može biti distinktivno ili redundantno prozodijsko obeležje i uz slogovni akcenat, a moraički sastav je značajan aspekat i silabičke strukture reči.

Konačno, na ovome mestu je potrebno reći i nekoliko reči o samom konceptu reči i njegovom značaju za akcentologiju. Kako je već rečeno, primarna funkcija slogovnog ili leksičkog akcenta jeste demarkacija pojedinačnih reči u kontinuiranom govornom nizu. Opšte je pravilo da jedna leksička reč uvek nosi i samo jedan slogovni akcenat, ne računajući sekundarne akcente i akcenatski eho (Garde, op. cit.: 43-45). Međutim, odnos leksičke i izgovorne reči nije uvek idealan, iako se obe definišu i preko akcenta. Izgovorna ili fonetska reč (akcenatska celina, takt) predstavlja segment govornog toka koji je objedinjen jednim slogovnim akcentom, ali koji ne mora nužno da se poklapa i s granicama leksičkih reči (Miletić 1952: 72). Rečenična ili sintagmatska intonacija može da izmeni kako akcenatske karakteristike pojedinačnih reči, dovodeći ih do deakcentuacije 
i kliticizacije, tako i inherentna obeležja govornih segmenata (Kašić 1980; 1985; 1990; 1997; Škarić 1970). U tom slučaju, više leksičkih reči može biti objedinjeno jednim realizovanim slogovnim akcentom, tako da čine i jednu izgovornu reč. Takvi su prozodijski mehanizmi kod određenih gramatičkih klasa ili oblika pojedinih reči i gramatikalizovani u artikulacionim bazama većine jezika, u kojima se akcentogene ili ortotoničke reči po tome razlikuju od klitičkih reči - najčešće enklitika ili proklitika; koje nikada ne nose i ne mogu da prime slogovni akcenat, već čine neakcentovani deo izgovorne reči s drugom akcentogenom rečju, prema utvrđenim pravilima enklize ili proklize koja važe u morfonologiji i sintaksi konkretnog jezika.

Iz navedenoga se o akcentu može zaključiti upravo to da je reč o reprezentativnom fenomenu lingvističkog interfejsa. Fonetska i fonološka obeležja prozodijske strukture iskaza neodvojiva su od gramatičke informacije - morfološke strukture reči, rečenične strukture i linearizacije i sl.; tako da se i slogovni akcenat (i njegovo odsustvo, u slučaju klitičkih reči), kvantitet i sintagmatski i rečenični akcenat i intonacija, kao prozodijska obeležja pojedinačnih morfema i reči, sintagmi i klauza, u potpunosti realizuju tek na interfejsu ili sumeđi fonološke i morfosintaktičke komponente jezika (cf. i Bresnan 1971; Inkelas \& Zec 1990; Jun 2005; Nespor \& Vogel 1986; Selkirk 1984).

\subsection{Slogovni akcenat u albanskom jeziku}

$\mathrm{U}$ tradicionalnom pristupu fonetici i fonologiji albanskoga (Beci 2004: 116-121; Demiraj 1984; Dodi 1990; 2004: 157-177; Hadaj 1991; Memushaj 2008), slogovni akcenat u artikulacionoj bazi albanskog jezika uglavnom se određuje kao dinamički, i najčešće kao morfonološki slobodan, u skladu sa tipološkim klasifikacijama o kojima je iznad bilo reči. Teško je, međutim, dati neko sigurnije određenje slogovnog akcenta u albanskome bez podrobnijih fonetskih i fonoloških analiza.

Tako se, recimo, uglavnom ističe da fonetsku bazu slogovnog akcenta u albanskom čine u prvome redu varijacije intenziteta, a redundantno i trajanja, zbog čega je reč o dinamičkoj akcentuaciji (Dodi, op. cit.: 166; cf. Jubani 2012); ali se, međutim, akustičkom analizom pokazuje i značajnija uloga frekvencije u realizaciji akcenatskog kontrasta, zbog čega Beci (op. cit.: 119) ističe da je fonetska priroda slogovnog akcenta u al- 
banskome ipak „kompleksnija“. Albanski, s druge strane, poznaje samo jednu vrstu slogovnoga akcenta, bez fonoloških razlika u tonalitetu ili trajanju između akcentovanih slogova u različitim pozicijama i rečima, zbog čega se $u$ fonološkom pogledu slogovni akcenat $u$ albanskom i može smatrati dinamičkim, pre nego tonskim odnosno visinskim, kao što su to, recimo, silazni i uzlazni konturni tonovi u štokavskome. Da albanski akcenat $\mathrm{u}$ fonološkom smislu zna samo za jednu, silaznu intonaciju, pokazuju i kontaktni govori zetsko-sandžačkog i kosovsko-resavskog dijalekta sa metataksom i duljenjem kratkog silaznog akcenta, kao i kontaktni prizrensko-timočki govori s duljenjem ekspiratornog akcenta, koji su nesumnjivo posledica bilingvizma (Stanišić 1995: 47-48; 2010: 159-160; v. i tamo navedenu literaturu).

Slično stoji i za mesto akcenta u albanskome. Beci (op. cit.: 116) tvrdi da ,akcenat pada na bilo koji slog prema složenim pravilima koja ponekad zavise i od gramatičkih kriterija“", a zatim i to da se ne može ni morfonološkim pravilima u potpunosti utvrditi mesto akcenta u albanskome, već da ono mora biti navedeno u leksikonu (ibid.: 118). Dodi (op. cit.: 172) navodi da albanski akcenat ,nije vezan ni za jedan određeni slog“ i „ne može se predstaviti nijednim opštim pravilom“, već predstavlja „obeležje reči kao leksičke i gramatičke jedinice“. S druge strane, mada se smatra slobodnim, akcenat $u$ albanskome je, uz malobrojne izuzetke, $u$ pravilu nepokretan u paradigmi (ibid.: 173), po čemu se, opet, razlikuje od tipično slobodnih, tj. morfološki mobilnih akcenata u drugim jezicima. I kontaktni govori u zonama s višim stepenom bilingvizma takođe pokazuju da postoji tendencija ka fiksiranju mesta akcenta u albanskome, budući da poznaju karakteristične neetimološke baritoneze (Stanišić, loc. cit.).

Tradicionalna gramatika okaziono prepoznaje akcenat na penultimi kao tendenciju ka fiksiranju mesta akcenta u albanskome, na nivou reči (Dodi \& Gjinari 1983: 129), unutar osnove (Buchholz \& Fiedler 1987: 53), odnosno u obliku određenog vida kod imenica (Camaj 1984: 8). Deskriptivnom analizom se, međutim, može jasno izdvojiti gramatička osnova reči kao domen unutar koga se određuje mesto slogovnog akcenta; svi su flektivni nastavci u pravilu ekstrametrični, tj. nikada ne nose akcenat, niti utiču na njegovo mesto u leksičkoj i izgovornoj reči, koje je metričkim pravilima vezano za određeni slog osnove. Osnove s metrički lakom ultimom (otvorenim slogom u čijem je nukleusu kratki monoftong) po pravilu 
imaju akcenat na penultimi (cf. lú $l_{\mu} e_{\mu}$ 'cvet' : lúlj-a, NOM.SG.DEF.; lúle-ve, DAT.PL.DEF.; itd.), dok osnove s teškom ultimom - zatvorenim slogom, diftongom u nukleusu, odnosno dugim vokalom u gegijskome - uvek nose akcenat na poslednjem slogu osnove (cf. lulishtá ${ }_{\mu}{ }_{\mu}$ 'cvećar'; lulishtari ${ }_{\mu \mu}$ 'cvećarstvo'; lulëzó $o_{\mu}(n)_{\mu}-j$ 'cvetam'). To će reći da je slogovni akcenat u albanskom osetljiv na metrički sastav gramatičke osnove reči, tj. na slogovni kvantitet ultime, te da je vezan za dva poslednja sloga flektivne osnove; dok je u konjugaciji to uvek poslednji slog osnove (Bozhoviq 2012; Canalis 2007).

Izuzetke od ovoga opšteg pravila predstavljaju određene klase osnova sa ultimom zatvorenom likvidom $(-l,-l l,-r)$, ređe nazalom ili spirantom $-s,-z$, u čijem nukleusu u nekim oblicima najčešće stoji kratki vokal $\ddot{e}$ ili $u$; uključujući i sve glagolske participe na-ur. Ove osnove nose akcenat na penultimi; dakle njihova ultima se metrički računa kao laka, iako je zatvorena kodom, pa i silabifikovana (npr. $f u_{\mu} t u r_{\mu}$ 'leptir'). Poseban metrički status likvida, međutim, nije i kroslingvistički nepoznat (cf. lat. muta cum liquida).

$\mathrm{S}$ druge strane, $\mathrm{u}$ derivaciji se mesto slogovnog akcenta gotovo uvek pomera dalje ka sufigiranom kraju osnove, ponovo i tu podležući metričkim restrikcijama dvaju poslednjih slogova osnove (lú $l_{\mu} e_{\mu}$ 'cvet'; lul$i_{\mu}$ shte ${ }_{\mu}$ 'cvećnjak'; lulisht-á $a_{\mu} r_{\mu}$ 'cvećar'; lulishtá ${ }_{\mu} r-e_{\mu}$ 'cvećarka'; lulishtar-í 'cvećarstvo'; itd.). Domen realizacije slogovnog akcenta u albanskome uvek je, dakle, gramatička (flektivna) osnova reči; kako prostih, tako i izvedenih.

Izuzetke i od ovoga opšteg pravila predstavljaju pojedini ekstrametrični sufiksi, kao što je to priloški sufiks $-a z i /-a z /-a s$, te patronimički sufiks $-a j$, koji zadržava metričku strukturu motivnog imena. I ovde se, međutim, kao što je slučaj i kod osnova sa likvidama i sl., ekstrametričnost sufiksa ogleda i u silabifikaciji i s njom povezanim segmentnim alternacijama, poput asilabičnosti i prelaza u poluvokal $i: j$ kod osnova na $-a j<-a-i$.

Ako se uzme u obzir sva napred iznesena građa, jasno je zašto je, prema Canalisu (op. cit.: 3), osetljivost slogovnog akcenta na metričku strukturu flektivne osnove reči u albanskome ,često vodila k zaključku da je albanski akcenat u suštini nepredvidljiv, budući da se može naći na bilo kojem od četiriju poslednjih slogova u reči, te da stoga mora biti označen u leksikonu“". Međutim, kako Canalis dalje ističe (loc. cit.): 
Ali ovo je stanovište zasnovano tek na posmatranju reči u celini; ako se vokali koji pripadaju flektivnim morfemama zanemare, $\mathrm{i}$ ako se uzme $\mathrm{u}$ obzir samo osnova, javlja se i mnogo jasniji i ograničeniji obrazac: akcenat je praktički uvek na poslednjem ili pretposlednjem slogu osnove. Otuda treba posmatrati osnovu kao relevantan domen akcenta, a ne flektivne oblike reči, i ne treba uzimati u obzir vokale u flektivnim morfemama, koji su uvek neakcentovani.

Nakon što smo u uvodnom poglavlju deskriptivno izložili osnove akcenatskog sistema albanskog jezika, u narednom delu rada ćemo više reči posvetiti njihovome teorijskom značaju i pristupima akcentuaciji albanskoga u okviru savremene fonološke teorije. Pre svega u okrilju generativne fonološke teorije, koja predstavlja i dominantni tok u fonologiji druge polovine XX veka i danas, javlja se i nekoliko teorijskih pristupa akcenatskom sistemu albanskoga jezika. O njima je reč u narednom poglavlju rada.

\section{Generativni pristupi akcentologiji albanskoga jezika}

Prvi generativni pristup fonologiji i akcentologiji albanskoga jezika (Bevington 1974) pripada klasičnoj fazi generativne fonologije, i o njemu je reč u prvome delu poglavlja. Paradigmatske karakteristike slogovnog akcenta u fleksiji i derivaciji u albanskome odgovaraju cikličkoj teoriji i leksikalističkom pristupu u fonologiji i morfologiji (Trommer 2013a), o kojima je reč u drugom delu poglavlja. S druge strane, fokus na metričku strukturu reči u albanskome, teoriju sloga i more, odnosno na sintagmatske karakteristike slogovnog akcenta, dominira u okviru metričke fonologije (Canalis, op. cit.), koja je uz leksičku fonologiju i najbliža postizanju deskriptivne adekvatnosti odgovarajućeg teorijskog modela.

Konačno, u završnom delu ovoga poglavlja govori se o teoriji optimalnosti i pristupima akcenatskom sistemu albanskoga jezika zasnovanima na njoj (Trommer 2013b). Teorija optimalnosti pomera fokus fonološke teorije sa posebnih pravila, koja važe $u$ artikulacionim bazama različitih jezika, na univerzalna fonološka ograničenja, čime se i najviše približava ostvarenju eksplanatornog cilja fonološke teorije. 
2.1. Generativna fonologija: standardni model (Bevington 1974)

Počeci generativne fonologije vezuju se pre svega za radove Chomskog i Hallea iz druge polovine pedesetih i šezdesetih godina, kojima je kritički revidiran tada aktuelni strukturalistički pristup jeziku američke škole distribucionalizma. Prvi je među njima bio generativni pristup akcenatskom sistemu engleskog jezika (u Chomsky et al., op. cit.), kojim je seminalno uvedena alternativa strukturalnoj fonologiji i utemeljena tzv. standardna (klasična) teorija generativne fonologije, definitivno izložena u celovitom fonološkom opisu engleskoga jezika nekih desetak godina kasnije (Chomsky \& Halle 1968). Standardni, ili tzv. SPE model (prema akronimu naslova cit. studije), inspirisan je i teorijom transformacione gramatike Chomskog (1957), koja jezik u celini posmatra mentalistički, kao autonoman kognitivni modul odnosno sistem univerzalnih principa i specifičnih pravila derivacije (transformacija), kojim su povezana dva nivoa reprezentacije jezika, tj. jezičke strukture: jedan koji je apstraktan - bazični, podležni, temeljni ili dubinski (D) nivo; i jedan konkretno realizovan, završni ili površinski (S) nivo (cf. Mihaljević 1991: 7-32 sqq.; Paunović 2003: 51-64).

$\mathrm{Na}$ taj način se u standardnom modelu generativne fonologije zapravo objašnjavaju u prvom redu morfonološke alternacije - kao proizvod dispariteta između D i S nivoa fonološke strukture; uključujući tu $\mathrm{i}$ akcenatski kontrast. Opisom transformacija u sistemu univerzalnih fonoloških obeležja, kojima se konkretni S nivoi generišu iz apstraktne $\mathrm{D}$ reprezentacije, omogućen je i veći stepen formalizacije u deskripciji fonološke građe, $u$ odnosu na strukturalistički pristup zasnovan na konceptu foneme i sistemu binarnih opozicija između fonoloških obeležja. Kada je reč o akcentu i uopšte suprasegmentnoj organizaciji govora, ipak, standardni generativni model pokazao se nedostatnim, jer je i akcenatski kontrast u njemu tretiran na isti način kao i segmentna govorna obeležja.

Tako i Bevington (op. cit.: 24-25) u svojoj seminalnoj studiji pravilo dodeljivanja slogovnog akcenta u albanskome formuliše, u skladu sa standardnim modelom, jednako kao i druga pravila transformacije u sistemu segmentnih fonoloških obeležja (1). Drugim rečima, u standardnoj teoriji generativne fonologije slogovni akcenat se posmatra kao fonološko obeležje [ $\alpha$ akcentovan], koje može imati vrednosti [+] i [-] kao i sva druga distinktivna obeležja govornih segmenata. 


$$
\text { a. } \left.\mathrm{V} \rightarrow[+ \text { akc. }] / \mathrm{C}_{0}\left\{\begin{array}{c}
e \\
a \\
o \\
\ddot{e}(\mathrm{C}) \\
\text { as } \\
\text { ull }
\end{array}\right\}\right]_{\text {osnova (-gl.) }}
$$

b. $\mathrm{V} \rightarrow[+$ akc. $\left.] / \mathrm{C}_{0}\right]_{\text {osnova }}$

Prema pravilu dodeljivanja akcenta formulisanom u (1), akcenat se $\mathrm{u}$ albanskome tipično nalazi na poslednjem slogu osnove reči, izuzev ako taj slog, u svim osnovama osim glagolskih, sadrži neku od nenaglašljivih kombinacija u (1a). Problem s ovako formulisanim pravilom, kako ističe Canalis (op. cit.: 5; cf. Bozhoviq, op. cit.: 144), ne zadržava se samo na nedostatku većeg stepena formalizacije, već ono ne uspeva ni na deskriptivnom nivou u potpunosti da obuhvati akcenatski sistem albanskoga izuzeci definisani u (1a) ne čine prirodnu klasu, već su svrstani skupa ad hoc; problematično je odvajanje glagolskih od svih drugih osnova jer se ne radi o fonološkom kriteriju; a ovako formulisanim pravilom nisu obuhvaćene ni imenice čija se osnova završava na naglašeno $-e,-a$ ili -o (kao kafé 'kafa'; pará 'novac'; byró 'biro' i sl.), osnove s vokalom $\ddot{e}$ u akcentovanom slogu (kao jastëk 'jastuk'), te jednosložne osnove s nekim od završetaka u (1a), koje prema ovome pravilu ne bi uopšte primile akcenat ( $f e ́$ 'vera'; $k a ́$ 'vo' i sl.), a ne radi se o klitikama. Pravilo u (1) ne pominje ni osnove sa neakcentovanim finalnim $-u r$, dok se za diftonške osnove, kod kojih je uvek akcentovan prvi deo diftonga, mora formulisati posebno pravilo dodeljivanja slogovnog akcenta (Bevington, op. cit.: 26; Canalis, ibid.).

Upravo stoga je i standardna teorija generativne fonologije pretrpela dosta kritika u pogledu načina na koji je pristupala prozodijskim obeležjima uopšte, tretirajući ih kao segmentna distinktivna obeležja - [ $\alpha$ silabički], [ $\alpha$ akcentovan], [ $\alpha$ dug]; ne obraćajući pažnju na strukturu sloga i jedinice veće od linearnih nizova segmenata (Paunović, op. cit.: 71 sqq.). Standardna teorija je, kako navodi i Mihaljević (op. cit.: 41) u pregledu generativne fonološke teorije, u najvećoj meri ,bila zaokupljena pravilima: njihovim poretkom, načinom primjene (ciklička, neciklička i iterativna primjena) i formalnom notacijom za njihovo formuliranje", i dalje (loc. cit.): 
Mnogojemanjepažnjeposvećenonaraviiustroju fonološkihreprezentacija. Standardna je teorija, nastavljajući tradiciju distribucionalističke (bloomfieldovske) fonologije, pretpostavljala da su fonološke reprezentacije linearni nizovi jedinica: na morfofonemskoj razini nizovi segmenata (koji su predstavljeni kao kompleksi glasovnih obilježja) i graničnih simbola, a na fonetskoj razini samo nizovi segmenata. Do raskida s takvom tradicijom došlo je u sedamdesetim godinama, a uzrok su bila proučavanja triju vrsta pojava koje su se tada počele intenzivnije izučavati: struktura sloga, naglasak i ton. [...] Otkriće tih pojava dovelo je do pomaka interesa istraživača sa sustava pravila na istraživanje naravi fonoloških reprezentacija i, kao rezultat tih istraživanja, do bitno bogatije i složenije koncepcije fonoloških reprezentacija.

Međutim, pre nego što se posvetimo morfonološkim reprezentacijama, u narednom delu poglavlja još će nešto reči biti o načinu primene pravila dodeljivanja slogovnog akcenta u albanskome. Ostajemo, dakle, još u domenu (mor)fonoloških pravila, iako ovde napuštamo standardni model generativne fonologije.

\subsection{Ciklička i leksička fonologija (Trommer 2013a)}

Definišući pravila derivacije morfonoloških $\mathrm{S}$ struktura iz $\mathrm{D}$ reprezentacije, već i u standardnoj teoriji generativne fonologije uočeno je da se upravo pravila akcentuacije ne primenjuju linearno, kao pravila segmentne organizacije govora, već se rekurzivno primenjuju od najnižih prema svakom višem morfonološkom konstituentu, u skladu s cikličkim transformacionim principom koji je poznat i iz transformaciono-generativne sintakse (cf. Mihaljević, op. cit.: 26-27). Međutim, iako je nesporno da takva pravila, nelinearna i rekurzivna, postoje i u fonologiji, posebno u domenu prozodije (Bresnan, op. cit.), veliki teorijski problem predstavlja definisanje domena fonološkog ciklusa - koja su pravila ciklična, čime je motivisana njihova ciklična primena, i kakav je odnos cikličkih pravila s gramatičkom strukturom reči odnosno iskaza (Mihaljević, ibid.).

Ciklička i leksička fonologija, u odnosu na klasičnu teoriju generativne fonologije, podrobnije proučavaju odnos (mor)fonoloških i gramatičkih procesa „u užem smislu“, ističući morfosintaktičku uslovljenost različitih fonoloških derivacija i fokusirajući se na fenomene 
fonološko-gramatičkog interfejsa u fleksiji i tvorbi reči. S time povezano aktuelno pitanje u teorijskoj lingvistici jeste i status morfologije (cf. Bermúdez-Otero 2011; Kiparsky 1979; 1982; Mohanan 1986; Mihaljević, op. cit., 32-37, 81-107; Paunović, op. cit.: 105-108).

\subsubsection{Imobilnost akcenta u fleksiji i stratalna teorija}

Kao što je iznad istaknuto, slogovni akcenat u albanskome osetljiv je na morfološku strukturu reči. To znači da je domen primene pravila dodeljivanja akcenta određen morfemskim granicama i morfološkim procesima. Pre svega, rečeno je kako su svi flektivni nastavci u albanskome ekstrametrični, što će reći kako nikada ne nose slogovni akcenat i, osim toga, kako je albanski akcenat $\mathrm{u}$ paradigmi nepomičan, tj. kroz sve flektivne oblike se nalazi na istom slogu gramatičke osnove. To je uočeno već i u tradicionalnom pristupu fonologiji albanskoga, mada tradicionalna gramatika ističe i izuzetke od tog opšteg principa (Dodi, op. cit.: 173), s naizgled mobilnim akcentom kod osnova singulara i plurala nekih imenica i prideva (kao njerí 'čovek' : njérëz 'ljudi'; babá 'otac' : baballárë 'očevi'; lúmë 'reka' : luménj 'reke'; i kéq 'loš, zao' : të këqínj 'loši, zli' i sl.).

Međutim, jasno je da se i ovde radi o ,izuzecima“ samo na nivou reči u celini. Ako se i ovi ,izuzeci“ posmatraju u domenu gramatičkih osnova singulara i plurala, oni se u svemu slažu s metričkim principima albanske akcentuacije o kojima je iznad bilo reči, a dodatno, i potvrđuju stanovište da je upravo flektivna osnova, a ne reč u celini, zapravo domen primene pravila dodeljivanja slogovnog akcenta $u$ albanskom jeziku, tj. da je slogovni akcenat u albanskome osetljiv na morfološki sastav reči, tako što se akcenatski kontrast realizuje samo u domenu gramatičke osnove; cf. imobilnost slogovnog akcenta u flektivnoj osnovi reči u okviru paradigme, u deklinaciji singulara i plurala (njerí : njerí-un, ACC.SG.DEF. itd.; njérëz : njérëz-it, NOM/ACC.PL.DEF. itd.). Morfonološka struktura o kojoj je reč odražava i istorijske promene u morfologiji albanskoga, kod pluralskih formanata tipa -inj, -enj, od starijih kolektiva, koji su remorfologizovani analogijom prema formantu plurala nazalnih osnova $-n j<*-n$-ai, kao u ftua 'dunja' : ftonj (pl.), na proširenje osnove -in, -en i pluralski nastavak $-j<*-a i$ (Bozhoviq, op. cit.: 145; Orel 2000: 230-231).

Kako pokazuje Trommer (2013a) u analizi mesta slogovnog akcenta $\mathrm{u}$ albanskome, njegova paradigmatska imobilnost u fleksiji upravo govori $\mathrm{u}$ prilog teorijama stratalne organizacije fonologije, koje pretpostavljaju 
da se različiti fonološki procesi odvijaju ciklički, u različitim uzastopnim morfološkim poddomenima derivacije (stratumima), te da fonologija $u$ celini nije monolitan i jednodimenzionalan jezički modul. Drugom rečju, prema Trommeru, slogovni akcenat se dodeljuje gramatičkim osnovama reči u jednoj fazi (stratumu) fonološke derivacije; u sledećoj, gde figuriraju flektivni oblici, akcenat ostaje na ranije utvrđenom mestu jer više ne učestvuje u fonološkoj derivaciji. Stoga se i jedino prema prozodijskoj strukturi gramatičke osnove može odrediti mesto slogovnog akcenta u reči, a ne i prema njenoj paradigmi. Prema Trommeru, dodatnu potvrdu tome pruža i postojanje defektnih paradigmi u albanskom, poput deponentnih glagola, koji nemaju oblike aktiva, već samo mediopasivne oblike koji su izvedeni, ali svejedno nose akcenat na onome slogu glagolske osnove na kome ga imaju i glagoli s punom paradigmom, što bi upravo ukazivalo na to da se metrička pravila dodeljivanja akcenta u albanskome primenjuju u ranijoj fazi derivacije na gramatičke osnove, čak i ako te osnove kasnije ne učestvuju u građenju svih paradigmatskih oblika lekseme; tj. da su (mor)fonološki procesi uopšte stratalne prirode. Dakle, za razliku od standardne teorije generativne fonologije, koja operiše s idejom jednodimenzionalnog fonološkog modula, ciklička odnosno leksička fonologija ukazuje na uzajamnu stratalnu organizaciju fonološke i morfosintaktičke informacije u leksikonu.

\subsubsection{Mobilnost akcenta u derivaciji i leksikalistička hipoteza}

Za razliku od imobilnosti akcenta $u$ fleksiji, slogovni akcenat $u$ albanskom je, kako je pokazano ranije, „mobilan“ u derivaciji, tj. iznova se ciklički dodeljuje svakoj sufigiranoj gramatičkoj osnovi. Prema teoriji o stratalnoj organizaciji leksikona, to bi značilo kako sufiksacija mora da prethodi fleksiji, inače pravila dodeljivanja akcenta, koja ne učestvuju u građenju flektivnih oblika u albanskome, ne bi delovala i u svim deriviranim osnovama reči, a ipak se - uz malobrojne izuzetke, o kojima je iznad bilo reči - primenjuju i nakon svake sufiksacije, pomerajući akcenat dalje k desnom kraju reči; što govori u prilog presintaktičkim teorijama morfologije, odnosno tzv. leksikalističkoj hipotezi (Chomsky 1972; Halle 1973).

S tim u vezi, ovde ćemo istaći dva pitanja povodom akcentuacije albanskoga koja imaju i širi teorijski značaj u svetlu leksikalističkog pristupa morfologiji. Prvo je, svakako, pitanje ekstrametričnih sufiksa o kojima je bilo reči iznad. Drugo pitanje tiče se odnosa prefiksacije i slaganja i slogovnog akcenta. 
Premda tradicionalna gramatika navodi više klasa neakcentovanih sufiksa u tvorbi reči u albanskome (Dodi, op. cit.: 176), većina njih zapravo sadrže metrički slab slog, zbog čega pravilno podležu metričkom principu dodeljivanja akcenta u osnovi reči u albanskome slogu koji prethodi sufiksu, dakle penultimi (takvi su priloški sufiksi -thi, -çe, mocioni sufiks $-e$ i sl.). Ekstrametrični sufiksi su priloški sufiks $-a z i /-a z /-a s$, te patronimički sufiks - $a j$, od kojih je prvi dvosložan, a ostali sadrže zatvoren slog (kao i sufiksi koji sadrže vokal ë u nukleusu, o kojima će više reči biti niže). Oba ova ekstrametrična sufiksa, međutim, pripadaju i usko definisanim klasama, sa značajnim potkategorizacionim ograničenjima. Priloški sufiks -azi / $-a z$ / -as u pravilu selektuje participske i pseudoparticipske osnove (kao u majtas 'levo' i djathtas 'desno' prema osnovama majtë i djathtë, koje i oblikom, i u derivaciji figuriraju kao participske osnove); dok patronimici na $-a j$ selektuju vlastita imena, a osim toga, kao i svi patronimici u albanskom, predstavljaju leksikalizovane flektivne oblike određenog vida imenice. Prema tome, derivacija ovim sufiksima ne pripada istome ciklusu odnosno stratumu kao i ostale sufiksacije u albanskom; tj. radi se o postleksičkoj departicipskoj tvorbi odnosno postsintaktičkoj leksikalizovanoj morfologiji.

Na sličan način se može postaviti i pitanje prefiksacije i slaganja u vezi s akcentom u albanskome. Iako za to ponekad postoje metrički uslovi, prefiks i prvi deo složenice nikada nisu akcentovani u albanskome, već se slogovni akcenat uvek nalazi na osnovi, odnosno na drugom delu složenice. To je u skladu i s organizacijom izgovorne reči u albanskom, gde su klitike uvek proklitike; tj. kako i slogovni akcenat inače teži da se pozicionira bliže desnom kraju osnove reči, tako su i svi metrički relevantni neakcentovani i klitički elementi u albanskom uvek u proklizi. Međutim, to takođe govori i o razlici između sufiksacije s jedne i prefiksacije i slaganja (i kliticizacije) s druge strane. Dok je prva presintaktički morfološki proces, potonji su postsintaktičke operacije.

\subsection{Metrička fonologija (Canalis 2007)}

S razvojem teorije sloga i moraičke teorije, klasična teorija generativne fonologije evoluirala je u pristupe koji su, kako je rečeno, fokus istraživanja sa fonoloških pravila preusmerili na fonološke reprezentacije 
- pre svega, metričku i autosegmentnu teoriju (Hayes 1995; Liberman \& Prince 1977; Mandić 2005a; 2005b; Hulst \& Smith 1982). Autosegmentna fonologija (Mihaljević, op. cit.: 62-78; Paunović, op. cit.: 81-96 sqq.) naročito pogoduje prikazu akcenatskih sistema s tonalnim opozicijama; kakve poznaje i srpskohrvatski, ali ne i albanski jezik. Stoga je i istraživanjima akcenatskog sistema albanskoga nešto primereniji klasični metrički pristup prozodijskoj strukturi reči i iskaza (Bozhoviq, op. cit.; Canalis, op. cit.).

Naime, pozicioniranje slogovnog akcenta unutar osnove reči u albanskom, u svim slučajima o kojima je iznad bilo reči, moguće je objasniti jedinstvenim metričkim načelima organizacije prozodijske strukture reči u slogove i stope. Slogovi se u albanskome razlikuju prema kvantitetu (težini) - teški su ili jaki kada su bimoraični $(\mu \mu)$, a laki ili slabi kada su monomoraični $(\mu)$. Moraička struktura flektivne (leksičke) osnove reči, a pre svega njenog desnog kraja, predstavlja i relevantni domen za primenu pravila dodeljivanja slogovnog akcenta u albanskome i organizaciju prozodijske strukture reči u odgovarajuće metričke stope; drugim rečima, albanski spada među jezike čija je metrička struktura osetljiva na slogovni (moraički) kvantitet, tzv. kvantitetski senzitivne jezike (Bozhoviq, op. cit.: 148-149; Canalis, op. cit.: 8). Prema ovim osnovnim metričkim načelima, moguće je definisati i sledeće opšte pravilo (2) o pozicioniranju slogovnog akcenta unutar reči u albanskom jeziku: „Unutar reči, primarni akcenat uvek pada na krajnji desni neparni trohej osnove, tj. na slog koji sadrži pretposlednju moru osnove reči“" (Canalis, loc. cit.).

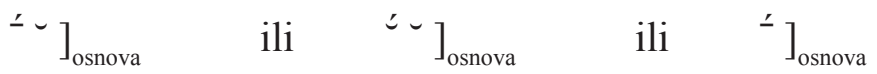

Prema opštem pravilu u (2), dakle, slogovni akcenat u albanskom se postavlja na ultimu osnove reči jedino ako je ona metrički teška (,,po prirodi" dug slog ili zatvoren kodom); u drugom slučaju, akcenat će se uvek naći na penultimi osnove (dakle, kada je ultima laka - bilo da su oba poslednja sloga osnove metrički laki, bilo da je ultima osnove laka, a penultima metrički teška). Jednom rečju, akcenat privlači pretposlednja mora osnove reči, tj. druga mora po redu zdesna; i on će se, prema tome, pozicionirati na onom slogu, jednom od poslednjih dvaju slogova osnove, koji sadrži tu moru. Tako se, jedinstvenim pravilom, objašnjavaju i svi primeri o kojima je iznad bilo reči; dakako, uz pomenute izuzetke, koje treba i posebno razmotriti. 
Ovako formulisanim pravilom, takođe, ujedno se objašnjava i silazni karakter svih diftonga u albanskom (kao i dugih vokala u gegijskome). Difonzi, naime, svojom unutrašnjom prozodijskom strukturom dodatno pružaju dokaz da je pozicioniranje slogovnog akcenta u albanskome moraički uslovljeno, tj. vezano za položaj mora, budući da su svi silaznog karaktera, s akcentom na prvome delu (ýe, ie, úe $\sim u$ u). Rečeno jezikom pravila (2), akcenat kod diftonga (i dugih vokala) pada na prvu moru sastavnicu slogovnog nukleusa, jer je to i pretfinalna mora osnove reči.

Primeri koji, kako pokazuje Canalis (op. cit.: 8-11), poseduju metrički defektnu ultimu, koja se uvek metrički računa kao laka, iako je zatvorena (najčešće likvidnom, ređe nazalnom ili stridentnom) konsonantskom kodom, dodatno svedoče o metričkoj prirodi slogovnog akcenta u albanskome. Međutim, nisu likvide, nazali i spiranti ti koji su u albanskom metrički defektni kada čine slogovnu kodu. Naprotiv, prema Canalisu, metrički je defektan slogovni nukleus koji sadrži vokal $\ddot{e}$, ili ređe $u$, a kojima se ne pridružuje vrednost niti jedne more. Kako ističe Canalis, vokal $\ddot{e}$ je ovde umetnut kasnije u fonološkoj derivaciji, kako bi zadovoljio fonotaktička ograničenja; on se ne nalazi i u bazičnoj fonološkoj reprezentaciji. Ispred velarizovane likvide $l l \mathrm{i}$, u nekim slučajima ispred $r$, javlja se i vokal $u$ kao poziciono uslovljena varijanta ovog ,sekundarnog“ $\ddot{e}$. S druge strane, kada vokal $\ddot{e}$ u zatvorenoj ultimi osnove reči prima akcenat kao i drugi vokali u tom položaju (kao u jastëk 'jastuk'), tj. kada nije metrički defektan, to po Canalisu ukazuje na njegovo prisustvo i u bazičnoj reprezentaciji, kao i na punopravan fonemski status u vokalizmu albanskoga. Drugom rečju, u albanskome računamo s dvema vrstama neutralnog vokala $\ddot{e} \mathrm{u}$ funkcionalnom, fonološkom smislu; s jednim /ə/ koje je fonemsko i prisutno u fonološkoj bazi, i s drugim $[\partial \sim \mathrm{u}]$ koje je fonetsko i ,sekundarno“, naknadno derivirano fonotaktičkim operacijama u nekim površinskim oblicima $-\mathrm{s}$ tim $\mathrm{u}$ vezi, izgleda da treba pretpostaviti da je silabifikacija već prisutna u bazičnoj reprezentaciji (Canalis, ibid.: 9 , fus.). Nije sigurno bez značaja ni segmentna reprezentacija ovakvih osnova, imajući u vidu da je i segmentni sastav takvih apstraktno silabičkih finalnih konsonanata strogo ograničen.

Osim unutar osnova reči, ovakvo ekstrametrično, ,sekundarno schwa“ nalazimo i u derivaciji, kod pojedinih sufiksa koji su uvek neakcentovani, a sadrže $\ddot{e}$ u zatvorenom slogu, kao što su to agentivni sufiks - $\ddot{e}_{s}\left(\right.$ shi $_{\mu} t_{\mu}{ }_{\mu}$ 'prodavac'; shi ${ }_{\mu} t \ddot{e} s e_{\mu}$ 'prodavačica') i pridevski sufiks $-s h(\ddot{e}) m \sim-c ̧(\ddot{e}) m(\stackrel{\mu}{i}$ 
sjéllshëm 'ljubazan'; e sjéllshme 'ljubazna'). I ovde je, međutim, metrička struktura reči u vezi s načinom njene derivacije, kao i kod ekstrametričnih sufiksa o kojima je bilo iznad reči. Naime, i ovde se u oba slučaja radi o postleksičkoj departicipskoj derivaciji, gde bazične reprezentacije ovih sufiksa glase $-s \mathrm{i}-s h m$, bez promena u akcenatskoj strukturi participske osnove (shit [ë]-s 'prodavac'; mësúe-s 'učitelj'; e sjéll[ë]-shm-e 'ljubazna' i sl.); a tek naknadno je, tamo gde fonotaktika albanskoga to zahteva, finalni konsonantski klaster razbijen jednim ,sekundarnim“ $\ddot{e}$.

Konačno, Canalis (op. cit.: 11-13) u opisu metričke strukture albanskoga pokazuje kako postoje i latentne more u toskijskom dijalektu. Naime, vodeći se opštim načelom u (2), ne mogu se objasniti finalni akcentovani slogovi vokalskih osnova kao shtëpi 'kuća', kafé 'kafa', babá 'otac' u toskijskom dijalektu albanskoga, ako se pretpostavi da je akcentovani slog u njima metrički lak, tj. monomoraičan. U gegijskome ovakve osnove sadrže dug, obično i nazalizovan vokal u akcentovanom slogu (shpi ${ }_{\mu \mu}$ 'kuća') ili imaju paroksitonezu ( $k a_{\mu} f e_{\mu}$ ' $k a f a ', b a_{\mu} b \ddot{e}_{\mu} \sim b a ́: b$ 'otac'); što je u bilo kom slučaju sasvim u skladu s pravilom (2). Da je, međutim, i u toskijskome takođe reč o teškoj, bimoraičnoj ultimi, Canalis pokazuje analizom flektivnih nastavaka koji figuriraju uz ove osnove; budući da $u$ toskijskome svaki konsonantski nastavak neposredno nakon akcentovane ultime osnove sadrži i jedno ,sekundarno“ $\ddot{e}$, i postaje silabički (cf. shtëpi 'kuća' : shtëpi-në, ACC.SG.DEF. : shtëpi-së, DAT.SG.DEF. itd.; di 'znam' : dí$m \ddot{e}, 1$ PL.IND.PRES.ACT. : dí-në, 3PL.IND.PRES.ACT. i sl.).

Prema tome, Canalis (ibid.) pretpostavlja da se u metričkoj strukturi ovih osnova i u toskijskome nalazi jedna latentna finalna mora, tj. jedan dodatni, latentni slog, koji omogućava pravilno trohejsko pozicioniranje slogovnog akcenta uz pretfinalnu moru, prema pravilu (2). Da je tako, pokazuje se u fleksiji, tako što „kada novi nastavak pronađe slogovni čvor lišen segmentnog materijala, on ga popuni“; pri tome, „,najmanje markirani vokal u albanskom vokalizmu, [ə], jeste i očekivani izbor za ovaj slogovni nukleus kada se on fonetski realizuje“ (ibid.: 12). Tako i schwa secundum u albanskome ima, zapravo, dvojaku funkciju na oba esktrema metričke reprezentacije reči - ono je, $\mathrm{u}$ isto vreme, fonetska realizacija i ametričnosti, i metričnosti (cf. i Jubani 2001). 


\subsection{Teorija optimalnosti (Trommer 2013b)}

Dok su metrički i autosegmentni pristup fokus istraživanja u generativnoj fonološkoj teoriji preusmerili sa sistema pravila na principe fonološke reprezentacije, teorija optimalnosti (cf. Paunović, op. cit.: 109116; Prince \& Smolensky 2004) uvela je potpuno novu perspektivu, orijentisanu na sistem fonoloških ograničenja. U okviru teorije optimalnosti (OT) sasvim je umanjen značaj fonoloških reprezentacija, jednako kao i pravila. Reprezentacije u krajnjem nisu važne jer je beskonačno mnogo mogućih kandidata koji se mogu generisati iz bazične strukture, kao i beskonačno potencijalnih bazičnih predložaka za generisanje optimalnog fonološkog kandidata. Ono što, prema tome, jeste važno jesu međusobno uređena univerzalna fonološka ograničenja, koja su sva i prekršiva, i koja na taj način, samo silinom svog međusobnog poretka u sistemu, relativnog ranga univerzalnih ograničenja, vrše selekciju optimalne završne forme.

Sva su fonološka ograničenja u OT, pri tome, univerzalna, dakle zajednička svim prirodnim jezicima, ali kako su i sva prekršiva-odatle dolaze i razlike među fonologijama posebnih jezika. U različitim konkretnim fonologijama, sistemi fonoloških ograničenja odlikuju se jedino različitim, hijerarhijski uređenim relativnim međusobnim rangom primene; drugim rečima, neka su ograničenja slabije prekršiva u jednim nego što su to $u$ drugim jezicima (npr. antihijatsko ograničenje, tj. ograničenje slogovnog pristupa, može biti češće prekršivo u nekim jezicima, ili pak u praksi skoro apsolutno neprekršivo, kao u praslovenskom; tako i ograničenje otvorenog sloga, npr. i u savremenom japanskom, i sl.). Što su manje prekršiva ograničenja u artikulacionoj bazi konkretnog jezika, to su ona i u njegovoj hijerarhiji (rangu) fonoloških ograničenja više relativno rangirana u odnosu na druga ograničenja. Naravno, kako nema i ograničenja koja su zapravo apsolutno neprekršiva, to je i uzrok kako međujezičke, tako i unutarjezičke fonološke varijacije i istorijskih glasovnih promena u jeziku.

I u pristupu slogovnom akcentu u albanskome potrebno je, dakle, utvrditi relativni rang (poredak) određenih metričkih ograničenja koji, na osnovu analize koja je izložena iznad, proizvodi i sve dobro formirane akcentovane reči albanskog jezika (cf. Maynard 1997). Jednu takvu analizu slogovnog akcenta u albanskome daje Trommer (2013b; cf. Bozhoviq, op. cit.: 145-147), koji za razliku od Canalisa (op. cit.), ne smatra da je 
akcenat u albanskome kvantitetski, već kvalitetski senzitivan. U jezicima sa slogovnim akcentom osetljivim na kvalitet sloga, slogovni akcenat teži da se pozicionira na onom slogu koji sadrži preferirani segmentni (vokalski) sastav. Veza između segmentne i suprasegmentne organizacije govornog niza nije i kroslingvistički nepoznata; u albanskom je, recimo, jasno uočljiva tendencija da slog koji sadrži vokal $\ddot{e}$ u nukleusu gotovo nikada ne bude akcentovan, posebno u gegijskom dijalektu. Trommer (op. cit.), tako, predlaže hijerarhiju osnovnih metričkih i segmentnih ograničenja (3), koja reflektuje i kvalitativnu osetljivost albanskog akcenta na segmentni sastav reči (prema Canalis, op. cit.: 6; radi jednostavnosti nisu prikazana sva relevantna ograničenja):

$$
\begin{aligned}
& \left.\left.\left.*[ə]]_{\sigma}\right]_{\text {osnova }}>>\text { težina/akcenat }\right]_{\text {osnova }}>*[- \text { zatvoren, },- \text { otvoren }]_{\sigma}\right]_{\text {osnova }} \\
& \left.>>\operatorname{DodELI}(\sigma, \text { desni, osnova, desni })>P[+ \text { zatvoren }]_{\sigma}\right]_{\text {osnova }}>*[+ \text { otvo- } \\
& \text { ren } \left.]_{\sigma}\right]_{\text {osnova }}
\end{aligned}
$$

Ograničenjem Dodeli( $\sigma$, desni, osnova, desni), slogovni akcenat se u albanskome postavlja na desni kraj osnove reči; međutim, naglasak na srednjem vokalu je blokiran ograničenjem * [- zatvoren, - otvoren $\left.]_{\sigma}\right]_{\text {osnova }}$ (,ne akcentovati srednji vokal na ultimi osnove reči"), koje je više rangirano u hijerarhijskom poretku ograničenja (3), što bi trebalo da reflektuje, prema Trommeru, kvalitativnu tendenciju da su srednji vokali $e$, o u ultimi osnove retko, iako ne i nikad, akcentovani u albanskom (cf. pállto 'kaput', i sl.). Ipak, i srednji vokali u albanskom primaju akcenat kada se nalaze u zatvorenom slogu, što je reflektovano ograničenjem težina/ akcenat $]_{\text {osnova }}$, koje je više rangirano od prethodnoga, i zahteva da metrički teška ultima osnove reči ponese slogovni akcenat. Konačno, budući da je srednji vokal $\ddot{e}$ najređe akcentovan u albanskome, čak i kada se nalazi u zatvorenom slogu, najviše je rangirano ograničenje $\left.*[\partial]{ }_{\sigma}\right]_{\text {osnova }}($, ,nemoj akcentovati ultimu osnove koja sadrži vokal $\ddot{e} \mathrm{u}$ nukleusu“). Niže od opšteg metričkog ograničenja Dodeli $(\sigma$, desni, osnova, desni) u hijerarhiji ograničenja (3), rangirana su ograničenja $\left.*[+ \text { zatvoren }]_{\sigma}\right]_{\text {osnova }}$ (,ne akcentovati zatvoreni vokal u ultimi osnove reči“) i $*\left[+ \text { otvoren }{ }_{\sigma}\right]_{\text {osnova }}($, ,ne akcentovati otvoreni vokal u ultimi osnove reči“"), što reflektuje tendenciju 
da su, pre svega, vokali $i$ i $a$ najčešće akcentovani u albanskome kada se nalaze u ultimi osnove, te su prema tome i poslednji prekršivi, sukladno rangu ograničenja u (3). Trommer, zapravo, rang ograničenja (3) i daje na osnovu analize frekvencije vokala u akcentovanim slogovima $u$ albanskome. Ograničenja u (3), tako rangirana, prema Trommeru, treba da reflektuju upravo realnostatističke frekvencijske činjenice o akcentovanim slogovima u albanskom jeziku. Uz to, Trommer na osnovu njih izvodi i zaključke o tipološkim odlikama albanske akcentuacije, dajući hijerarhiju naglašljivosti vokala prema njihovom položaju u vokalskom trouglu (4). Prema ovoj hijerarhiji, periferni vokali (najotvoreniji $a$ i najzatvoreniji $i, u$, zatim i y) teže da budu akcentovani pre nego srednji vokali, među kojima, opet, periferni $e, o$ teže slogovnom akcentu pre nego centralni vokal $\ddot{e}(\mathrm{Ca}-$ nalis, op. cit.: 6-8; Trommer \& Grimm 2004).

$$
/ \text { iuay } />/ \text { e o/ }>/ \text { / } /
$$

Međutim, kako ističe Canalis (ibid.), Trommerov pristup je problematičan na više mesta. Osim što ni na deskriptivnom planu ne objašnjava u potpunosti sve primere, i njegova teorijska podloga je $s$ tipološkog stanovišta donekle ekscentrična, budući da su hijerarhijski sistemi naglašljivosti kao u (4), zasnovani na periferalnosti vokala, a ne na sonornosti, kroslingvistički nepoznati, pa i protivni empirijskom stanju s kojim se tipološki zaista susrećemo u vokalizmima različitih jezika. Canalisovim rečima (loc. cit.), Trommerova su fonološka ograničenja „više deskriptivna nego što se čine eksplikativna“ i „vrednost je njegovih ograničenja samo statistička“.

Ipak, teorija optimalnosti je u stanju da prikaže, opiše i objasni različite fonološke fenomene na znatno formalniji i elegantniji način nego mnoge od njenih prethodnica u okviru generativne fonološke teorije. Imajući u vidu metričku strukturu albanskoga u celini, opisanu iznad, može se formulisati i odgovarajuća hijerarhija ograničenja pre svega metričke prirode koja bi ispravno generisala i sve realno ostvarene primere (Bozhoviq, op. cit.: 150), vodeći računa upravo o kvantitetskoj senzitivnosti slogovnog akcenta u albanskom jeziku. 


\section{Fonološko-gramatički interfejs}

Kao što se vidi u prethodna dva poglavlja rada, akcenatski sistem albanskoga u znatnoj je meri povezan i sa gramatičkom strukturom morfološkom strukturom reči, te sintaktičkom strukturom iskaza. Akcenat je i uvek već po sebi fenomen interfejsa - pre svega, realizuje se u vidu fonetsko-fonološkog interfejsa kao sistem funkcionalnih vrednosti određenog skupa fonetskih (artikulaciono-akustičkih i auditivno-akustičkih) obeležja; zatim, kao morfološko i leksičko obeležje reči, (slogovni) akcenat realizuje se i na interfejsu fonologije i morfologije; te kao obeležje izgovorne reči, u procesima kao što je sandhi i sl., pri kliticizaciji i linearizaciji rečenice, u prozodijskoj organizaciji iskaza i sl., slogovni akcenat ujedno pripada i domenu fonološko-sintaktičkog interfejsa.

Tako, nešto više ćemo ovde reći o akcentu u konjugaciji i kliticizaciji i linearizaciji klitičkoga niza uz glagolsku osnovu u albanskome, budući da je reč o zanimljivom kompleksu raznovrsnih segmentnih alternacija, takođe povezanih i s mestom akcenta u glagolskoj osnovi, odnosno odsustvom akcenta u klitičkim rečima. Reč je o procesima na sumeđi morfonologije i sintakse koji se odlikuju i svojom morfonološkom i svojom sintaktičkom posebnošću.

\subsection{Akcentuacija i morfologija infektuma}

Tradicionalna gramatika albanskoga (ali i neki generativni pristupi; kao Bevington, op. cit.) uglavnom ističe kako se, za razliku od imenskih osnova, koje su trohejske, tj. teže paroksitonezi, slogovni akcenat u konjugaciji uvek nalazi na ultimi osnove. To je tačno, ali treba primetiti da pri tome nema nikakvih značajnih razlika između metričke strukture i načina dodeljivanja slogovnog akcenta u imenskim i glagolskim osnovama. Naime, ultima glagolskih osnova je uvek metrički teška (jaka), te prema tome uvek i nosi slogovni akcenat; a ne zato što se prozodijski sistemi u deklinaciji i konjugaciji u albanskome međusobno razlikuju. Reč je o istome principu koji je izložen u (2), iako položaj akcenta u glagolskim osnovama i u albanskome, istorijski posmatrano, jeste i proizvod starijih akcenatskih razlika u deklinaciji i konjugaciji u praindoevropskom, gde su svi finitni glagolski oblici bili enklitični. 
Međutim, metrička vrednost ultime inflektuma u albanskome često je zamaskirana segmentnim alternacijama, među kojima su, naročito, alternacije finalnog $n: j$ i $n: \varnothing$. Kako pokazuje i Trommer (2013a), morfološku analizu infektuma u tradicionalnoj deskriptivnoj gramatici albanskoga (5), koja razlikuje tri klase glagola s trima tipovima promene infektuma i trima serijama prezentskih nastavaka (punoj 'radim' : shes 'prodajem' : $d i$ 'znam'), treba revidirati sa više formalizacije, tako da se dobije zapravo jedinstven morfonološki obrazac, kao u (6).
a. puno-j
shes- $\varnothing$
di-Ø 'znam'
b. puno-n
shet- $\varnothing$
di-Ø 'znaš'
c. puno- $n$
shet- $\varnothing$
di-Ø 'zna'
d. puno-jmë
shes-im
di-më 'znamo'
e. puno-ni
shit-ni
di-ni 'znate'
f. рипо-јпё
shes-in
di-në 'znaju'

(6)
a. punój-Ø
shes- $\varnothing$
di-Ø 'znam'
b. punón-Ø
shet- $\varnothing$
di-Ø 'znaš'
c. punón-Ø
shet- $\varnothing$
di-Ø 'zna'
d. punój-m[ë]
shes-[i]m

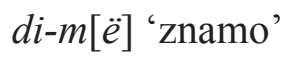
e. punó $[\varnothing]-n i$
shit-ni
$d i-n i$ 'znate'
f. punój- $n[\ddot{e}]$
shes-[i]n
$d i-n[\ddot{e}]$ 'znaju'

Analiza u (6) ima znatno više prednosti nego tradicionalna deskriptivna analiza $u(5)$. Ne samo što je sada vidljivo da su sve ultime osnove zaista metrički teške, jer su zatvorene kodom (N. B. glagoli III vrste imaju latentnu finalnu moru, kako pokazuje Canalis, op. cit.), već su ujednačeni i nastavci svih triju glagolskih klasa (vokali $\ddot{e}$ i $i$ u 6d. i 6f, prema Canalisu, naknadno figuriraju uz finalni akcenat, odnosno iz fonotaktičkih razloga), a ujednačene su i sve segmentne alternacije u njima - tako, alternacijama $t: s$ i $e: i$ u paradigmi II vrste pravilno odgovaraju alternacije $n: j$ i $n: \varnothing$ u paradigmi I vrste (potonja u 6e; Trommer je mišljenja da je reč o fonotaktičkom uprošćavanju geminate $n-n$, ali da se zaista radi o morfonološkoj alternaciji potvrđuju drugi oblici infektuma - mediopasiv, gde i Trommer daje $j: \varnothing$, imperfekat i imperativ). Konačno, analiza u (6) odgovara i istorijskoj bazi konjugacije u albanskome, jer su i dijahronijski posmatrano glagolske osnove infektuma I vrste zaista bile nazalne, a ne 
vokalske osnove, tj. nazal je u njima i istorijski deo osnove, a ne nastavka (cf. i dijalekatske oblike punonj 'radim' < punon-j, kao i kap-i 'hvatam', i sl.).

\subsection{Klitički niz u albanskom jeziku}

Kao što je rečeno iznad u radu, sve klitike u albanskome jesu proklitike. Njihova je rečenična linearizacija, međutim, određena i sintaktički, ne samo prozodijski; tako što se nalaze u proklizi isključivo uz glagol, ne i uz druge rečenične konstituente. Klitički oblici objekatskih zamenica redupliciraju se $u$ albanskome, pod određenim gramatički i pragmatički definisanim uslovima, proklitički uz glagol kada je iskazan i direktni ili indirektni objekat u vidu imenske sintagme, ili pak oba (cf. Malja-Imami 2013) - u potonjem slučaju, dolazi i do različitih fenomena sandhija kod udvojenih klitičkih zamenica, poput kraze i elizije vokala (7).

$$
\begin{aligned}
& \text { a. múa } \| m \ddot{e}=k a=d h \ddot{n} \ddot{e} \\
& \text { 'dao / dala mi je' (bukv. meni mi ima dato) } \\
& \text { b. múa } \| m a=(<m \ddot{e}+e) \text { dhá } \\
& \text { 'dao / dala mi ga / ju je' (bukv. meni mi ga / je dade) }
\end{aligned}
$$

Kada je, dakle, više od jedne klitičke reči u rečenici - ne samo usled reduplikacije objekatskih zamenica; sve se klitike grupišu skupa u jedan klitički niz (klaster, grozd), koji se pozicionira proklitički uz glagol. Međusobni redosled zameničkih i glagolskih klitika pri tome je sasvim gramatikalizovan: zameničke klitike uvek se pozicioniraju ispred glagolskih, tj. glagolske klitike (koje uključuju oblike pomoćnog glagola, kao u 7a) pozicioniraju se bliže glagolu, a za njima tek slede i zameničke klitike na levom kraju, a fonetskom početku izgovorne reči. I redosled zameničkih klitika je gramatički uređen, tako da klitika indirektnog objekta (pronominalna klitika u dativu) uvek prethodi klitici direktnog objekta (klitici u akuzativu). Uz to, klitički niz je poziciono ograničen jedino u odnosu na položaj glagola u rečenici; za razliku od srpskohrvatskih enklitika, u albanskome nema drugih ograničenja, dakle javlja se i na inicijalnoj poziciji u klauzi, odnosno fonetskoj frazi - ne samo zato što su sintaktička pravila 
linearizacije rečenice u albanskome takva, već upravo stoga što je prozodijska organizacija izgovorne reči u albanskome takva da se istaknuti elementi pozicioniraju bliže njenom desnom kraju, a prozodijski neistaknuti elementi zauzimaju inicijalnu poziciju. Na nivou iskaza, reč je, dakle, o jampskoj strukturi, za razliku od trohejske stope na nivou reči. Tu su, dakle, metrički i sintaktički sistem pravila samo dve, uzajamno zavisne, strane jednog istog fenomena fonološko-sintaktičkog interfejsa.

Uz (potvrdne) oblike imperativa, međutim, klitički niz sa objekatskim zamenicama ili s mediopasivnom (refleksivnom) klitičkom rečcom $u$ nalazi se i u enklizi uz glagol. Enkliza je, međutim, blokirana kada je u imperativu prisutna negacija. Pri tome, niz se enklitički pozicionira uz osnovu imperativa, tako da je razdvaja od njenog pluralskog nastavka (8).

$$
\begin{aligned}
& \text { a. shikóje }(<\text { shikó }=e<\text { e shikó }) \\
& \text { 'gledaj ga / je' } \\
& \text { b. shikóje-ni }(<\text { shikó-ni }=e<\text { e shikó-ni }) \\
& \text { 'gledajte ga / je' } \\
& \text { c. mós } \| e^{=} \text {shikó / shikó-ni } \\
& \text { 'ne gledaj/te ga / je' } \\
& \text { d. * mós || shikóje / shikóje-ni }
\end{aligned}
$$

Jasno, nije klitika ta koja se zapravo sintaktički pomera na postverbalnu poziciju, već se glagol, tačnije glagolska osnova, podiže na sintaktički višu, a praznu poziciju, ostavljajući klitiku za sobom, na njenoj prozodijski i sintaktički definisanoj poziciji u fraznoj strukturi iskaza; a zatim se koriguje i prozodijska struktura, tako da se klitika ponovo prozodijski priključi glagolu, samo ovoga puta u enklizi. To je evidentno i na osnovu blokiranoga podizanja imperativa u (8d), gde je ova sintaktička pozicija već zauzeta negacijom mos. Ono što je ovde, međutim, zanimljivo jesu implikacije takvog imperativskog podizanja za širu teoriju fonološkosintaktičkog interfejsa, morfološku i sintaktičku teoriju i sl., posebno za odnos između klitika i negacije, kao i imperativa i negacije (Kallulli 1995; Tomić 2001; Turano 2000). 


\subsection{Zaključak}

Akcenatski sistem albanskoga jezika predstavlja oblast vrednu istraživanja, u više različitih aspekata. Iako su većina tradicionalnih pristupa, uključujući dijalektologiju i arealnu lingvistiku, uporednoistorijsku lingvistiku i deskriptivnu gramatiku, strukturalnu fonetiku i fonologiju; kao i većina glavnih pristupa u okviru generativne fonologije, uključujući standardni model, cikličko-leksičku fonologiju, metričku teoriju i teoriju optimalnosti, već primenjena pri opisu akcenatskog sistema albanskog jezika, malo je u njima bilo pokušaja da se dobijeni nalazi i uopštê na jedan viši teorijski i eksplanatorni nivo.

Razmatrajući fonološko-gramatički interfejs slogovnog akcenta na materijalu albanskog jezika, u radu smo pokazali kako je akcenatski kontrast u albanskom jeziku osetljiv ujedno na metričku i morfološku strukturu reči i izraza, te kako se slogovni akcenat i njegovo odsustvo u slučaju klitičkih reči i ekstrametričnih nastavaka, sufiksa i prefiksa, ostvaruju unutar složenog sistema prozodijske i morfosintaktičke organizacije govornog signala. Tradicionalne tipološke klasifikacije akcenatskih sistema pokazuju se previše redukcionističkim kada je o slogovnom akcentu reč. U tom smislu, akcenatski sistem albanskoga predstavlja važnu referentnu tačku i za opštelingvističke generalizacije, pre svega, tipologije akcenatskih sistema i fenomena fonološko-gramatičkog interfejsa u teoriji jezika uopšte.

\section{Literatura}

Beci, B. (2004). Fonetika e gjuhës shqipe. Tiranë: EDFA.

Belić, A. (1931). L'accent de la phrase et l'accent du mot. Travaux du Cercle linguistique de Prague 4: 183-188.

Bermúdez-Otero, R. (2011). Cyclicity. In M. van Oostendorp et al. (eds.), The Blackwell Companion to Phonology, vol. 4, 2019-2048. Oxford - Malden: Blackwell.

Bevington, G. (1974). Albanian Phonology. Wiesbaden: Otto Harrassowitz. Boriçi, L. (1987). Intonacioni dhe funksionet e tij në gjuhën shqipe. Studime filologjike 41: 75-87. 
Bozhoviq, Gj. (2012). Theksi i fjalës në morfonologji të shqipes: teoria metrike dhe e optimalitetit. Seminari Ndërkombëtar për Gjuhën, Letërsinë dhe Kulturën Shqiptare 31(1): 143-152.

Bresnan, J. (1971). Sentence Stress and Syntactic Transformations. Language 47: 257-281.

Buchholz, O. \& W. Fiedler (1987). Albanische Grammatik. Leipzig: VEB Verlag. Camaj, M. (1984). Albanian Grammar. Wiesbaden: Otto Harrassowitz.

Canalis, S. (2007). To What Extent is Albanian Word Stress Predictable? In A. Bisetto \& F. Barbieri (eds.), Proceedings of the XXXIII Incontro di grammatica generativa, 1-14. Bologna: Università di Bologna.

Chomsky, N. \& M. Halle (1968). The Sound Pattern of English. New York: Harper \& Row.

Chomsky, N. (1957). Syntactic Structures. The Hague - Paris: Mouton.

Chomsky, N. (1972). Remarks on Nominalization. In Studies on Semantics in Generative Grammar, 11-61. The Hague - Paris: Mouton.

Chomsky, N. et al. (1956). On Accent and Juncture in English. In M. Halle (ed.), For Roman Jakobson: Essays on the Occasion of His Sixtieth Birthday, 65-80. The Hague - Paris: Mouton.

Clark, J. \& C. Yallop (1990). An Introduction to Phonetics and Phonology. Oxford - Malden: Blackwell.

Crowhurst, M. \& A. Teodocio Olivares (2014). Beyond the Iambic-Trochaic Law: The Joint Influence of Duration and Intensity on the Perception of Rhythmic Speech. Phonology 31: 51-94.

Cruttenden, A. (1997). Intonation. Cambridge - New York: Cambridge University Press.

Demiraj, Sh. (1984). Theksi në gjuhën shqipe. Studime filologjike 2.

Dodi, A. \& J. Gjinari (1983). Fonetika dhe gramatika e gjuhës së sotme letrare shqipe, II: Fonetika. Tiranë: Akademia e Shkencave e Shqipërisë - Instituti i Gjuhësisë dhe i Letërsisë.

Dodi, A. (1986). Ndarja aktuale e fjalisë dhe intonacioni në gjuhën shqipe. Gjuha jonë 4.

Dodi, A. (1990). Theksi dhe shkallëzimi i tij në gjuhën shqipe. Gjuha jonë 2.

Dodi, A. (2004). Fonetika dhe fonologjia e gjuhës shqipe. Tiranë: Akademia e Shkencave e Shqipërisë - Instituti i Gjuhësisë dhe i Letërsisë.

Fox, A. (2000). Prosodic Features and Prosodic Structure: The Phonology of Suprasegmentals. Oxford - New York: Oxford University Press. 
Garde, P. (1993). Naglasak. Zagreb: Školska knjiga.

Gjinari, J. (1981). Zanoret hundore të gegërishtes dhe ë-ja e theksuar e toskërishtes. Studime filologjike 3.

Hadaj, G. (1991). Shpërndarja e theksave në leksikun e shqipes. Studime filologjike 1.

Halle, M. (1973). Prolegomena to a Theory of Word Formation. Linguistic Inquiry 4: 3-16.

Hayes, B. (1985). Iambic and Trochaic Rhythm in Stress Rules. In N. Niepokuj et al. (eds.), Proceedings of BLS 11: Parasesion on Poetics, Metrics, and Prosody, 429-446. Berkeley: Berkeley Linguistic Society.

Hayes, B. (1995). Metrical Stress Theory: Principles and Case Studies. Chicago: University of Chicago Press.

Hulst, H. van der \& N. Smith (eds.) (1982). The Structure of Phonological Representations, I, II. Dordrecht: Foris.

Hulst, H. van der (2010). Word Accent: Terms, Typologies and Theories. In H. van der Hulst et al. (eds.), Stress Patterns of the World, II: The Data, 3-54. Berlin: Mouton de Gruyter.

Hulst, H. van der (ed.) (2014). Word Stress: Theoretical and Typological Issues. Cambridge - New York: Cambridge University Press.

Hyman, L. (2014). Do All Languages Have Word Accent? In Hulst (2014), 56-82.

Inkelas, S. \& D. Zec (eds.) (1990). The Phonology-Syntax Connection. Chicago - Stanford: University of Chicago Press - CSLI Publications.

Jakobson, R. (1971). Über die Betonung und ihre Rolle in der Wort- und Syntagmaphonologie. Selected Writings, I: Phonological Studies, 117-136. The Hague - Paris: Mouton.

Jubani, A. (2001). Rreth ecurisë së $\ddot{e}$-së së patheksuar në gjuhën shqipe. Studime albanologjike 1: 127-145.

Jubani, A. (2012). Acoustic Features of the Accent in the Albanian Language. VIII International Workshop on Balto-Slavic Accentology (IWoBA VIII), 6-8. jul 2012, Filozofski fakultet Univerziteta u Novom Sadu.

Jun, S. A. (2005). Prosodic Typology. In S. A. Jun (ed.), Prosodic Typology: The Phonology of Intonation and Phrasing, 430-458. Oxford - New York: Oxford University Press. 
Kallulli, D. (1995). Clitics in Albanian. University of Trondheim Working Papers in Linguistics 24. Dragvoll: University of Trondheim.

Kašić, Z. (1980). Glasovne promene u proklizi u srpskohrvatskom jeziku. Naš jezik 24(4-5): 217-246.

Kašić, Z. (1985). Glasovne promene u enklizi. Naš jezik 26(4-5): 228-233.

Kašić, Z. (1990). Sandhi i neutralizacija distinktivnih obeležja. Književnost i jezik 1: 71-73.

Kašić, Z. (1997). Promene glasova uslovljene ritamsko-intonacionom organizacijom govora. Beogradska defektološka škola 1: 77-82.

Kašić, Z. (2000a). Segmentna i suprasegmentna organizovanost govora. U S. Golubović \& Z. Kašić, Segmentna i suprasegmentna organizovanost govora i poremećaji fluentnosti, 9-62. Beograd: Društvo defektologa Jugoslavije.

Kašić, Z. (2000b). Funkcija suprasegmenata u govornom izrazu. Beogradska defektološka škola 2-3: 113-124.

Kiparsky, P. (1979). Metrical Structure Assignment is Cyclic. Linguistic Inquiry 10: 421-441.

Kiparsky, P. (1982). From Cyclic Phonology to Lexical Phonology. In Hulst \& Smith (1982), 131-175.

Ladd, R. (1996). Intonational Phonology. Cambridge - New York: Cambridge University Press.

Lehiste, I. (1970). Suprasegmentals. Cambridge, MA: MIT Press.

Liberman, M. \& A. Prince (1977). On Stress and Linguistic Rhythm. Linguistic Inquiry 8: 249-336.

Malja-Imami, N. (2013). Udvajanje objekta u balkanskom jezičkom arealu. Anali Filološkog fakulteta 25(2): 47-59.

Mandić, D. (2005a). Metrička fonologija. Suvremena lingvistika 59-60: 81-101.

Mandić, D. (2005b). Autosegmentna fonologija i naglasak. Jezikoslovlje 6(1-2): 171-193.

Mandić, D. (2007). Naglasak. Fluminensia 19: 77-94.

Martinet, A. (1954). Accents et tons. Miscellanea Phonetica 2: 13-24.

Martinet, A. (1982). Osnove opće lingvistike. Zagreb: Grafički zavod Hrvatske.

Maynard, K. (1997). An Optimality Analysis of Albanian Word Stress. In L. Xingzhong et al. (eds.), Papers from the 1997 Mid-America Linguistics Conference, 94-100. 
Memushaj, R. (2008). Theksi i fjalës në gjuhën shqipe. Studime albanologjike 1: 37-49.

Mihaljević, M. (1991). Generativna i leksička fonologija. Zagreb: Školska knjiga.

Miletić, B. (1952). Osnovi fonetike srpskoga jezika. Beograd: Znanje.

Mohanan, K. (1986). The Theory of Lexical Phonology. Dordrecht: D. Reidel.

Nespor, M. \& I. Vogel (1986). Prosodic Phonology. Dordrecht: Foris Publications.

Orel, V. (2000). A Concise Historical Grammar of the Albanian Language: Reconstruction of Proto-Albanian. Leiden - Boston - Köln: Brill.

Paunović, T. (2003). Fonetika i/ili fonologija? Kritički prikaz fonoloških teorija XX veka. Niš: Prosveta.

Peco, A. (1991). Osnovi akcentologije srpskohrvatskog jezika. Beograd: Naučna knjiga.

Pike, K. (1972). The Intonation of American English. In D. Bolinger (ed.), Intonation, 53-83. Harmondsworth: Penguin.

Prince, A. \& P. Smolensky (2004). Optimality Theory: Constraint Interaction in Generative Grammar. Oxford - Malden: Blackwell.

Revithiadou, A. (2004). The Iambic/Trochaic Law Revisited: Lengthening and Shortening in Trochaic Systems. In B. Arsenijević et al. (eds.), Leiden Papers in Linguistics 1(1): 37-62.

Roach, P. (1982). On the Distinction Between 'Stress-Timed' and 'SyllableTimed’ Languages. In D. Crystal (ed.), Linguistic Controversies, 73-79. London: Edward Arnold.

Selkirk, E. (1984). Phonology and Syntax: The Relation Between Sound and Structure. Cambridge, MA: MIT Press.

Stanišić, V. (1995). Srpsko-albanski jezički odnosi. Beograd: Balkanološki institut SANU.

Stanišić, V. (2010). Srpsko-albanski fonološki odnosi između uticaja i arealnog jedinstva. U J. Grković-Mejdžor \& M. Radovanović (ur.), Teorija dijahronijske lingvistike i proučavanje slovenskih jezika, 159-176. Beograd: Srpska akademija nauka i umetnosti.

Škarić, I. (1970). Glasovne promjene unutar izgovorne riječi. Jezik 5: 134-145.

Tomić, O. Mišeska (2001). Negation and Imperatives. In G. Zybatow et al. (eds.), Current Issues in Formal Slavic Linguistics, 159-168. Frankfurt am Main: Peter Lang. 
Trommer, J. \& A. Grimm (2004). Weight and Sonority in Albanian Word Stress. The Twelfth Manchester Phonology Meeting, 20-22 May 2004, University of Manchester.

Trommer, J. (2013a). Stress Uniformity in Albanian: Morphological Arguments for Cyclicity. Linguistic Inquiry 44: 109-143.

Trommer, J. (2013b). Albanian Word Stress. Balkanistica 26: 183-221.

Trubetzkoy, N. (1958). Anleitung zu phonologischen Beschreibungen. Göttingen: Vandenhoek \& Ruprecht.

Trubetzkoy, N. (1968). Grundzüge der Phonologie. Göttingen: Vandenhoek \& Ruprecht.

Turano, G. (2000). On Clitics and Negation in Albanian. Rivista di grammatica generativa 25: 81-117.

Zec, D. (1997). O prozodijskoj strukturi reči. Južnoslovenski filolog 53: 35-58.

Đorđe Božović

\section{Summary}

\section{THE PHONOLOGY-GRAMMAR INTERFACE IN LEXICAL STRESS}

The paper presents a synthesis of the research on word stress in Albanian. Theoretical approaches to Albanian word stress are analysed according to their descriptive and explanatory adequacy, as well as in relation to the questions they pose within wider theoretical, morphological and syntactic contexts, given that lexical stress is seen in the paper as a representative phenomenon of the interface of phonology (prosody) and the morphosyntactic component. 